\title{
Study of thermal and mechanical properties of a biocomposite based on natural rubber and $45 \mathrm{~S} 5$ Bioglass ${ }^{\circledR}$ particles
}

\author{
M. J. Silva ${ }^{1}$ V. O. Soares ${ }^{2}$ G. C. Dias ${ }^{2}$ - R. J. Santos ${ }^{1}$ • A. E. Job ${ }^{3}$ • \\ A. O. Sanches ${ }^{4} \cdot$ J. A. Malmonge ${ }^{4}$
}

Received: 18 June 2016/ Accepted: 26 October 2016/Published online: 11 November 2016

(C) Akadémiai Kiadó, Budapest, Hungary 2016

\begin{abstract}
Biocomposites based on natural rubber (NR) reinforced with 45S5 Bioglass ${ }^{\circledR}$ (BG) particles were obtained by casting/evaporation method in which NR was dissolved in chloroform and mixed with BG particles. Structural, mechanical, and thermal tests were performed on the biocomposites to evaluate the influence of $\mathrm{BG}$ particles on the properties of the NR matrix. Thermogravimetric tests (TG/DTG) of the biocomposites showed decomposition profiles similar to that of NR, and the main peak of the DTG curve was well defined in the temperature range $300-450{ }^{\circ} \mathrm{C}$, characteristic of the structural degradation of NR. The TG analysis also revealed that the thermal stability of the samples increases with the increasing quantity of BG in the biocomposite. DMA tests showed higher storage modulus $\left(E^{\prime}\right)$ values for samples with larger amounts of BG; however, above the $T_{\mathrm{g}}$, the $E^{\prime}$ value tended to zero due to the increased mobility of the polymer chains. By analyzing $\tan \delta$, the $T_{\mathrm{g}}$ values were calculated to be -46 and $-50{ }^{\circ} \mathrm{C}$ for NR and the biocomposite samples, respectively. Mechanical testing demonstrated that the addition of BG to the biocomposite
\end{abstract}

M. J. Silva

michael@rosana.unesp.br

1 Engenharia de Energia, UNESP - Univ. Est. Paulista, Campus de Rosana, Rosana, SP, Brazil

2 Departamento de Ciências, UEM - Univ. Est. de Maringá, Campus de Goioerê, Goioerê, PR, Brazil

3 Departamento de Física, Faculdade de Ciências e Tecnologia, UNESP - Univ. Est. Paulista, Campus de Presidente Prudente, Presidente Prudente, SP, Brazil

4 Departamento de Física e Química, Faculdade de Engenharia, UNESP - Univ. Est. Paulista, Campus de Ilha Solteira, Ilha Solteira, SP, Brazil improved the mechanical properties of the samples. The samples became more rigid with the increasing quantity of $\mathrm{BG}$, as demonstrated by decreasing deformation and the increasing elastic modulus $(Y)$ and breaking strength of the samples. The BG particles positively affected the mechanical and thermal properties of the biocomposite, allowing its use in biomedical applications.

Keywords Biocomposite - Natural rubber - Bioglass ${ }^{\circledR}$. Thermal analysis $\cdot$ Mechanical analysis

\section{Introduction}

Biomaterials are capable of replacing, repairing, or treating biological tissues in living organisms [1,2]. These materials include metals, polymers, ceramics, and composites and can be classified according to their chemical nature (i.e., natural or synthetic) [3, 4]. In addition, based on the reaction of the tissue to the biomaterial, they are classified into three distinct categories: bioactive, bioinert, and bioresorbable. Bioactive materials have the property of forming chemical bonds with the tissue. Bioinert materials do not interact with biological tissues when introduced in the body. Bioresorbable materials start to dissolve (resorb) upon placement within the human body and are slowly replaced by advancing tissue [3].

Bioactive glasses or Bioglass $\AA$ (BG) was discovered in 1969, but they were only approved for medical use in 1985 . The first commercial product was sold under the trade name 45S5 Bioglass ${ }^{\circledR}$ and has since been used in several biomedical fields [5]. 45S5 Bioglass ${ }^{\circledR}$ is still the most well-known bioactive glass developed, and it is claimed to be osteoinductive and osteoconductive [6,7]. This glass has an approximate composition of $46.3 \mathrm{SiO}_{2}, 24.3 \mathrm{Na}_{2} \mathrm{O}$, 
$26.9 \mathrm{CaO}$, and $2.5 \mathrm{P}_{2} \mathrm{O}_{5}(\mathrm{~mol} \%)$ [8]. It has been tested over several years and demonstrates excellent results in bone regeneration $[5,9]$. Although $45 \mathrm{~S} 5$ Bioglass $\AA$ is one of the most studied and used biomaterials in tissue engineering, it nevertheless presents some disadvantages due to its poor mechanical properties, especially for applications that require high mechanical stresses [10-12].

To overcome this problem, biocompatible polymers have been used as supports for bioactive glasses to obtain biocomposites [11-14]. These biocomposites are required when applying bioactive glasses in situations involving high mechanical stresses. Thus, these new biomaterials inherit the biocompatible and bioactive properties of bioactive glasses and the excellent mechanical properties of polymers. Biocomposites based on polymers and bioglasses have been investigated in tissue engineering research [14-17], with widespread applications such as surgical materials [15], artificial cartilage [11], drug delivery systems [18], and dental implants [19]. However, the choice of polymer for biomedical applications or tissue engineering depends on its use, i.e., whether the replacement or treatment is for soft or hard tissue $[1,20]$.

Many researchers have incorporated BG particles into biocompatible synthetic polymeric matrices, such as PVA [21], PLA [22], PLLA [23], and PLGA [24]. Another class of polymers that has gained attention for bioactive glass supports are natural polymers, such as collagen [25], polyhydroxybutyrate $[26,27]$, cellulose nanowhiskers (CNW) [28], and polyurethane based on castor oil [29]. Natural polymers present mechanical properties that are superior or similar to those of synthetic polymers. Furthermore, they are obtained from natural resources and present good biocompatibility with living tissues. A natural polymer that deserves special mention is natural rubber (NR). NR is a biopolymer of high molecular weight consisting of isoprene units linked in cis-1,4 conformation [30]. This material is inexpensive to produce, comes from a raw material from renewable sources, and offers excellent mechanical properties $[2,31]$. Traditionally, NR has been used in many industrial applications such as gloves and tires. More recently, it has exhibited excellent results as a biomaterial for replacing skin [32-34], for accelerating bone formation, as a drug release device, and as a vascular prosthesis [34-37]. To the best of our knowledge, a biocomposite using NR and 45S5 Bioglass ${ }^{\circledR}$ has never been reported in the literature.

Therefore, NR was chosen as a support for 45S5 Bioglass ${ }^{\circledR}$ particles due to its excellent mechanical properties and potential applications in tissue engineering. In the present study, the influence of BG particles on the structural, thermal, and mechanical properties of the NR matrix was evaluated.

\section{Experimental}

\section{Natural rubber membranes}

The NR latex was collected from Hevea brasiliensis trees (RRIM 600 clones) located at an experimental farm at the São Paulo State University (UNESP) campus in Ilha Solteira-SP-Brazil. After collection, the NR latex was sieved and stored at approximately $5{ }^{\circ} \mathrm{C}$. NR membranes were prepared by casting the NR latex onto a glass substrate and drying it in air at $60{ }^{\circ} \mathrm{C}$ for $12 \mathrm{~h}$. After drying, the membranes were easily removed from the substrate.

\section{S5 Bioglass® particles}

The BG raw materials were melted to obtain a $\mathrm{BG}$ composition of $24.3 \mathrm{Na}_{2} \mathrm{O}, 26.9 \mathrm{CaO}, 2.5 \mathrm{P}_{2} \mathrm{O}_{5}, 46.3 \mathrm{SiO}_{2}$ (mol\%), which is widely known as $45 \mathrm{~S} 5$. The following raw materials were used: sodium carbonate $\left(\mathrm{Na}_{2} \mathrm{CO}_{3}-\mathrm{JT}\right.$ Baker), calcium carbonate $\left(\mathrm{CaCO}_{3}\right.$ - JT Baker), disodium phosphate $\left(\mathrm{Na}_{2} \mathrm{HPO}_{4}\right.$ - JT Baker), and high-purity quartz ( $\mathrm{SiO}_{2}$ - Santa Rosa).

The components were melted together in a conventional bottom-loaded electric furnace (CM Furnaces, Inc, Bloomfield, NJ) at $1450{ }^{\circ} \mathrm{C}$ for $4 \mathrm{~h}$ in a platinum crucible. The molten glass was then poured into a stainless steel mold and air-cooled. Glass pieces were first obtained by grinding the solid glass in an agate mortar to obtain large particles $(\sim 2 \mathrm{~mm})$. These particles were then crushed in a high-impact planetary ball mill (Pulverisette 5-FRITSCH) at $450 \mathrm{rpm}$ for $90 \mathrm{~min}$ using an agate jar and agate balls $20 \mathrm{~mm}$ in diameter.

\section{Biocomposite preparation}

To obtain the biocomposites, $4 \mathrm{~g}$ of the NR membrane was dissolved in $40 \mathrm{~mL}$ of chloroform under constant stirring for $12 \mathrm{~h}$. The chloroform/NR solution exhibited a gel-like appearance and a viscosity appropriate for dispersing BG particles.

BG particles were previously dispersed in $10 \mathrm{~mL}$ chloroform under constant stirring for $1 \mathrm{~h}$. The BG particles/ chloroform dispersion was slowly poured into the chloroform/NR solution and kept under stirring by $5 \mathrm{~h}$. This solution was casted into a glass substrate and dried in air at $60{ }^{\circ} \mathrm{C}$ for $12 \mathrm{~h}$. At that point, the chloroform was completely volatilized, resulting in the NR/BG biocomposite.

Different amounts of BG particles were used in the above process to obtain various NR/BG biocomposites. The mass ratios of NR and BG were 90/10, 70/30, and $50 / 50$. The biocomposites were characterized in order to 
evaluate the influence of BG particles on their structural, mechanical, and thermal properties.

\section{Characterization}

A scanning electron microscope (SEM, EVO LS15 Zeiss) was employed to observe the microstructure of fractured transversal sections of the samples coated with carbon for $30 \mathrm{~min}$. The biocomposites were fractured after immersion in liquid nitrogen and then dried under dynamic vacuum for $1 \mathrm{~h}$.

The surface morphology was characterized using an Agilent 5500 atomic force microscope on samples with an area equal to $1 \mathrm{~cm}^{2}$.

Thermogravimetric testing (TG/DTG) was carried out using TA Instruments model Q600 in the temperature range of $25-600{ }^{\circ} \mathrm{C}$ at a heating rate of $10{ }^{\circ} \mathrm{C} \mathrm{min}{ }^{-1}$ in a nitrogen atmosphere with a flow rate of $100 \mathrm{~mL} \mathrm{~min}^{-1}$, and about $10 \mathrm{mg}$ was used for each sample. Dynamic mechanical thermal analysis (DMA) was performed using a Netzsch model DMTA 242C in the tensile mode with a frequency of $10 \mathrm{~Hz}$ in the temperature range from -100 to $150{ }^{\circ} \mathrm{C}$ using a heating rate of $5{ }^{\circ} \mathrm{C} \mathrm{min}^{-1}$. Rectangular specimens with dimensions of approximately $9 \mathrm{~mm} \times 3 \mathrm{~mm} \times 1 \mathrm{~mm}$ were used for the test. The metrics obtained in this analysis were the storage modulus $\left(E^{\prime}\right)$, loss modulus $\left(E^{\prime \prime}\right)$, and $\tan \delta$ (the ratio between $E^{\prime \prime}$ and $E^{\prime}$ ).

The mechanical tests (stress-strain mode) were performed according to ISO 37:2011 using an Instron model 3639 tensometer at room temperature with a crosshead speed of $13 \mathrm{~mm} \mathrm{~min}{ }^{-1}$ applied to a $100-\mathrm{N}$ load cell. Mechanical measurements were repeated eight times according to ISO 1286:2006.

\section{Results and discussion}

\section{Morphology}

Scanning electron microscopy was performed on fractured transversal sections and the surface of the biocomposites to evaluate their morphologies and investigate the dispersion of BG particles inside the NR matrix. As shown in Fig. 1a, $\mathrm{b}$, and $\mathrm{c}$, the BG particles were homogeneously distributed within the NR/BG biocomposites, confirming that the used method was reliable. In addition, a homogeneous pattern can be observed in the surface of biocomposites, as shown in Fig. 1d. The presence of BG particles on the biocomposite surface is important so that these particles are available to interact with the organic tissue. As shown in Fig. 1e, BG particles exhibited an irregular geometry, and their mean particle size was less than $10 \mu \mathrm{m}$.
The surface of the biocomposites was analyzed using atomic force microscopy (AFM). Figure $2 a, b$ shows the morphological characteristics of the surfaces of the samples with mass ratios of $90 / 10$ and 50/50, respectively. The $50 / 50$ biocomposite shows a rougher surface than that of the $90 / 10$ biocomposite due to its higher BG particle content, corroborating the SEM images.

\section{Thermal analyses}

The thermal behavior of NR and the biocomposite samples (under an inert atmosphere) is shown in Fig. 3a, b. The thermal decomposition parameters including onset temperature $\left(T_{\mathrm{on}}\right)$, the temperature at the maximum decomposition rate $\left(T_{\mathrm{m}}\right)$, and the residue are summarized in Table 1. As shown in Fig. 3a, b, the NR and the biocomposite samples present similar decomposition profiles, considering the temperature range of $25-600{ }^{\circ} \mathrm{C}$. Figure $3 \mathrm{~b}$ shows the first-derivative TG curves in which changes in the rate of mass loss can be seen in three different temperature ranges $50-150,200-320$, and $300-450{ }^{\circ} \mathrm{C}$. The mass loss for temperatures below $150{ }^{\circ} \mathrm{C}$ is attributed to water evaporation. The mass loss in the temperature range 200-320 ${ }^{\circ} \mathrm{C}$ is assigned to the decomposition of non-rubber components, such as fatty acids, in which the mass loss is approximately $7 \%[40,41]$. The mass loss in the temperature range $300-450{ }^{\circ} \mathrm{C}$ (the most intense peak shown in Fig. 3b) is due to the structural decomposition of NR chains and corresponds to approximately $88,74,56$, and $41 \%$ for the NR, 90/10, 70/30, and 50/50 samples, respectively $[38,39]$. For the NR, the maximum rate of mass loss occurs at $365{ }^{\circ} \mathrm{C}$, as exhibited by the most intense peak in Fig. 3b. Biocomposites present the maximum rate of mass loss in the temperature range 376-378 ${ }^{\circ} \mathrm{C}$, as shown in Table 1 , and consequently, they show higher thermal stability than the NR.

Figure $3 \mathrm{a}$ shows that the permanent residue above $450{ }^{\circ} \mathrm{C}$ increases with the content of BG particles in the biocomposites. This behavior is expected because the $\mathrm{BG}$ particles are thermally stable up to $600{ }^{\circ} \mathrm{C}$, and so this $\mathrm{TG}$ analysis allows estimating the amount of BG particles in each biocomposite by the permanent residue values above $450{ }^{\circ} \mathrm{C}$, which are 49,34 , and $15 \%$ for the $50 / 50,70 / 30$, and 90/10 samples, respectively. These values are close to the nominal amounts of BG particles used in the experimental process.

Figure 4 shows the dynamic mechanical analysis of NR and the biocomposites. Figure 4a shows the storage modulus $\left(E^{\prime}\right)$ curve as a function of temperature for all samples. Below $-65^{\circ} \mathrm{C}$, all samples show a plateau, and the $E^{\prime}$ values increase with the content of BG particles. This behavior indicates that the $\mathrm{BG}$ particles increase the capacity of the NR matrix to support mechanical stresses 
Fig. 1 SEM micrographs of the fractured transversal sections of NR/BG biocomposites in the mass ratios a 90/10, b 70/30, and c 50/50. d SEM of the surface of the 50/50 sample and e BG particles
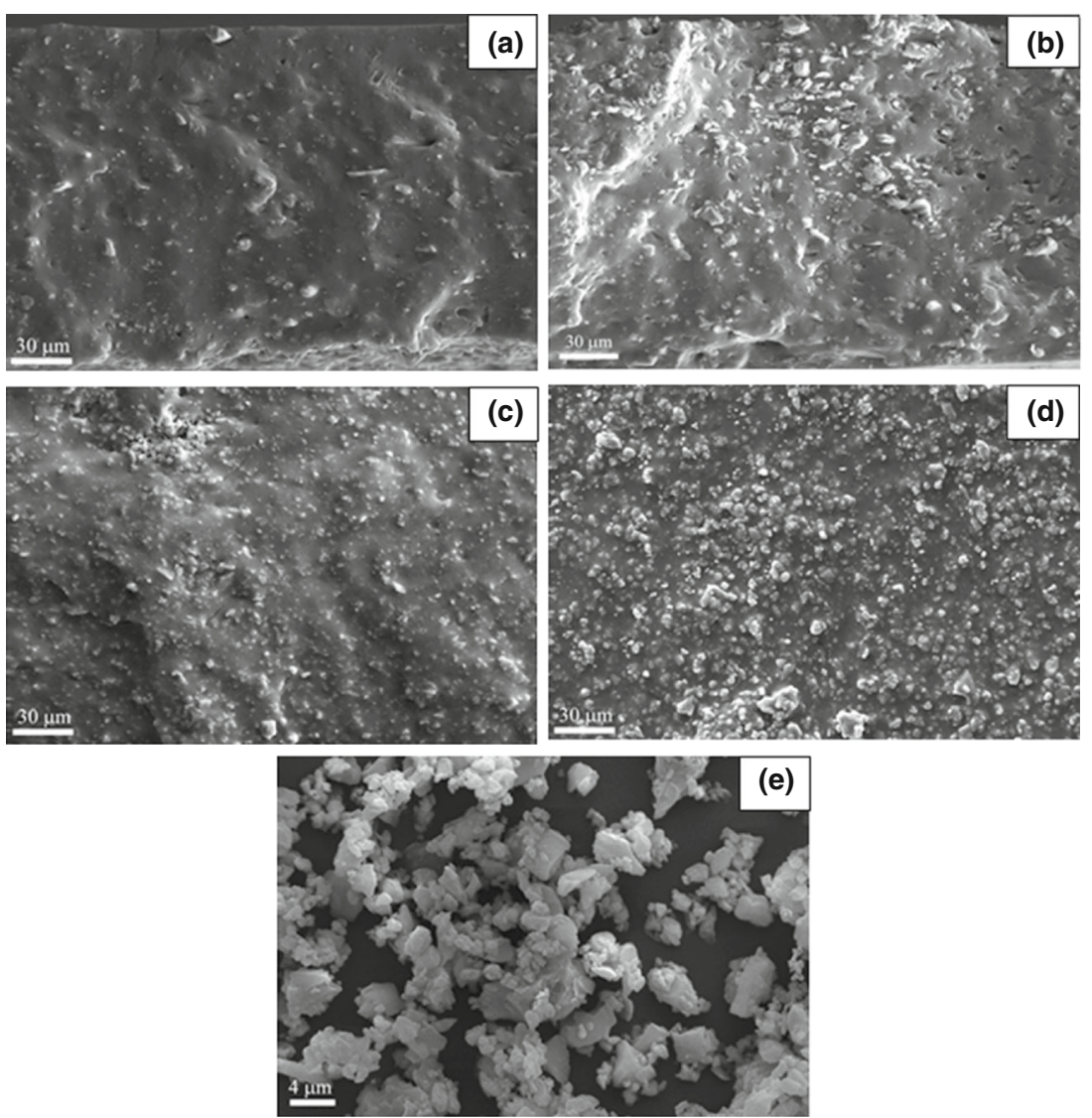

with recoverable deformation [42]. For temperatures below $-65^{\circ} \mathrm{C}$, NR chains are not mobile because this temperature range is below the glass transition temperature $\left(T_{\mathrm{g}}\right)$ of NR. The BG particles also act as a reinforcement in the matrix, and the applied load is transferred to these particles, thereby increasing $E^{\prime}$. This behavior can be attributed to the good interaction between the BG particles and the NR matrix. Near the $T_{\mathrm{g}}$ of NR (temperature range of -70 to $-40{ }^{\circ} \mathrm{C}$ ), a strong decrease in $E^{\prime}$ values with increasing temperature is observed for all samples. This decrease is attributed to the dissipation of vibrational energy due to the increased mobility of the NR chains; i.e., the NR starts to flow, and little or no energy is stored in the biocomposite. As shown in Fig. 4a, the thermal properties of NR do not change significantly with the incorporation of BG particles.

The loss modulus $\left(E^{\prime \prime}\right)$ as a function of temperature is shown in Fig. $4 \mathrm{~b}$ for all samples. The $E^{\prime \prime}$ represents the ability of the material to dissipate energy, mainly in the form of heat during cyclic deformation. As shown in Fig. $4 \mathrm{~b}$, the intensity of the $E^{\prime \prime}$ peak increases with the BG particle content in the biocomposites. This behavior may be assigned to the inhibition of the relaxation process of polymer chains [43]. A shift in the $E^{\prime \prime}$ peak to lower temperatures with the increase in the BG particle content compared to NR was also observed. The Bioglass ${ }^{\circledR}$ is a hydrophilic particle and when incorporated in the natural rubber produces a plasticizing effect shifting $E^{\prime \prime}$ to lower temperature [44].

DMA is an alternative common method for measuring $T_{\mathrm{g}}$ of polymer composites [45]. The relaxation process, which is represented by a peak on the $\tan \delta$ curve, involves the cooperative motions of polymer chains $[43,46]$, and the peak temperature corresponds to the $T_{\mathrm{g}}$ of the polymer [42]. The relaxation process observed in Fig. 4c for all samples is denoted as $\alpha$ and involves the cooperative motions of polymer chains [43, 46]. As shown in Fig. 4c, the relaxation peak of NR shows a higher intensity than that of the biocomposites, which is due to the higher elasticity of NR and its greater tendency to dissipate energy during deformation compared to that of biocomposites. All biocomposites show a $T_{\mathrm{g}}$ of $-50{ }^{\circ} \mathrm{C}$ (Fig. 4c). The lower $T_{\mathrm{g}}$ value of the biocomposites compared to NR were 
attributed to plasticizing effect promoted by hydrophilic particle, as mentioned above. Similar effect was observed with polyurethane reinforced with cellulose nanowhiskers [44]. Biocomposites with 30 and 50 mass\% BG are above the mechanical percolation stabilizing the $T_{\mathrm{g}}$ value.

The Cole-Cole diagram shown in Fig. 5 represents $E^{\prime \prime}$ as a function of $E^{\prime}$ for the NR and biocomposite samples. This analysis is very important for measuring the viscoelastic properties and the homogeneity of the composite. According to the Cole-Cole method, a homogeneous

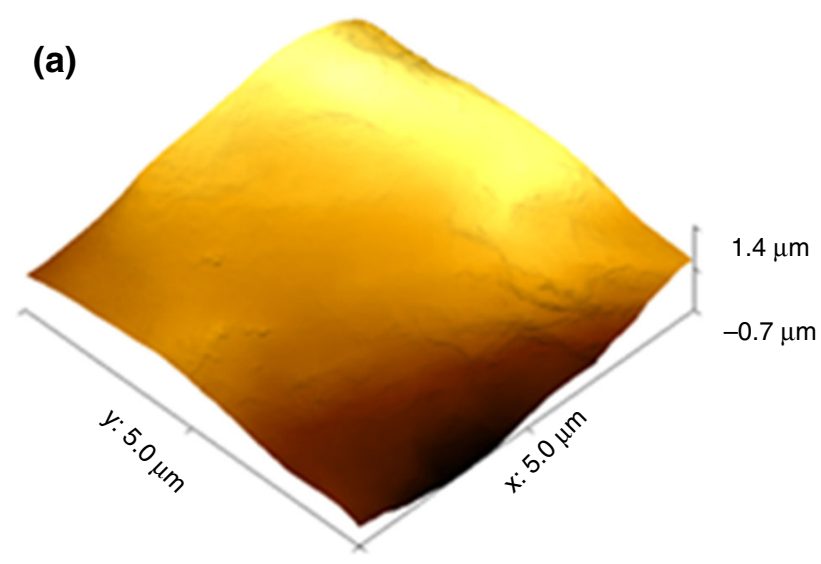

(b)

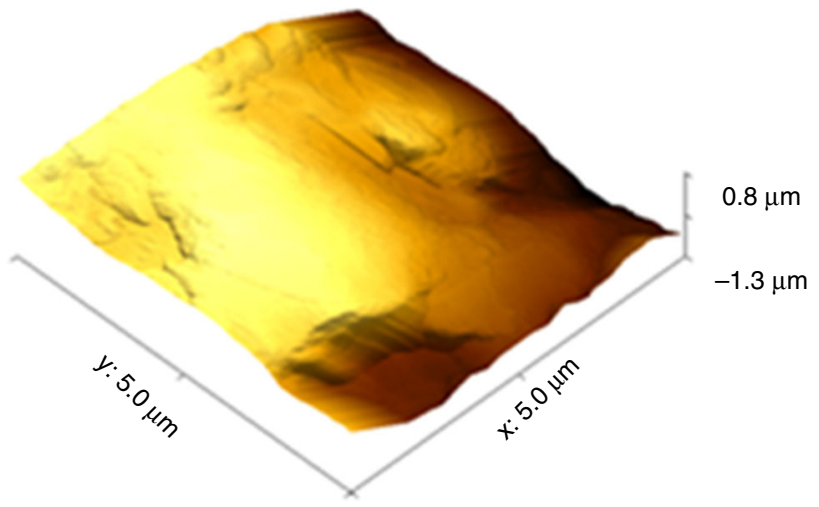

Fig. 2 AFM analysis of biocomposites in the mass ratios (NR/BG): a $90 / 10$ and b $50 / 50$

Fig. 3 a TG and a DTG curves of the biocomposites and NR polymeric system is expected to exhibit a semicircle on the Cole-Cole diagram [46, 47]. Figure 5 shows semicircles for all samples, indicating that the BG particles are distributed homogeneously within the biocomposite and that there is good adhesion between the NR and the BG.

\section{Mechanical properties}

Stress-strain tests were performed to evaluate the effect of BG particles on the mechanical properties of NR. Figure 6 and Table 2 show that the addition of $\mathrm{BG}$ particles increases several mechanical properties of NR because the tension applied to the NR matrix was transferred efficiently to the BG particles, thus confirming their role as reinforcement.

The typical stress-strain behavior of elastomeric materials is observed for NR, as shown in Fig. 6. The biocomposites' stress-strain curves are similar to each other; however, the elastic modulus $(Y)$ of the biocomposites increases with the BG particle content. The tensile strength at break $\left(\sigma_{\text {at break }}\right)$ also increases with the BG particle content. The increase in the elastic modulus of the material will also be an increased resistance to deformation. As shown in Fig. 6, adding only 10 mass\% of BG particles to the NR significantly increases its elastic modulus and $\sigma_{\text {at break. }}$

Table 2 shows that the elastic modulus of biocomposites increases gradually, acquiring a value of $(4.61 \pm 0.58)$ $\mathrm{MPa}$ for the 50/50 samples as compared to the $(0.41 \pm 0.03) \mathrm{MPa}$ for NR. This behavior suggests there is

Table 1 Thermal decomposition parameters: onset temperature $\left(T_{\mathrm{on}}\right)$, maximum decomposition rate $\left(T_{\mathrm{m}}\right)$, and residues of $\mathrm{NR}$ and NR/BG biocomposites

\begin{tabular}{llll}
\hline Samples & $T_{\text {on }} /{ }^{\circ} \mathrm{C}$ & $T_{\mathrm{m}}{ }^{\circ} \mathrm{C}$ & Residue/\% \\
\hline NR & 333 & 365 & 1.6 \\
NR/BG (90/10) & 328 & 376 & 15 \\
NR/BG (70/30) & 320 & 378 & 34 \\
NR/BG (50/50) & 331 & 377 & 49 \\
\hline
\end{tabular}

(a)

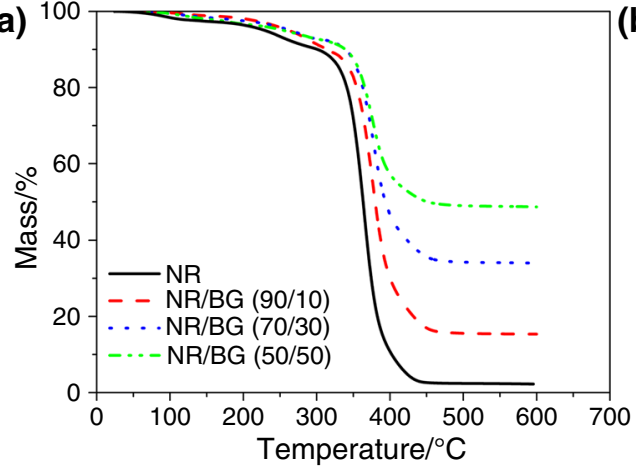

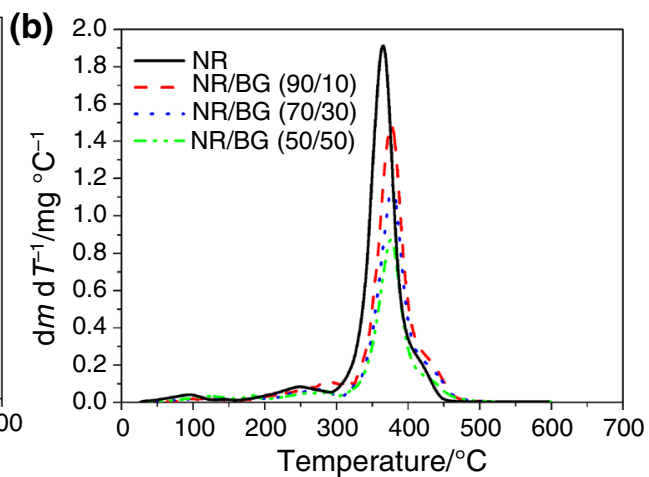


Fig. 4 Dynamic mechanical thermal analysis of the NR/BG biocomposites and NR.

a Storage modulus $\left(E^{\prime}\right)$, b loss modulus $\left(E^{\prime \prime}\right)$, and $\mathbf{c} \tan \delta$ as a function of temperature
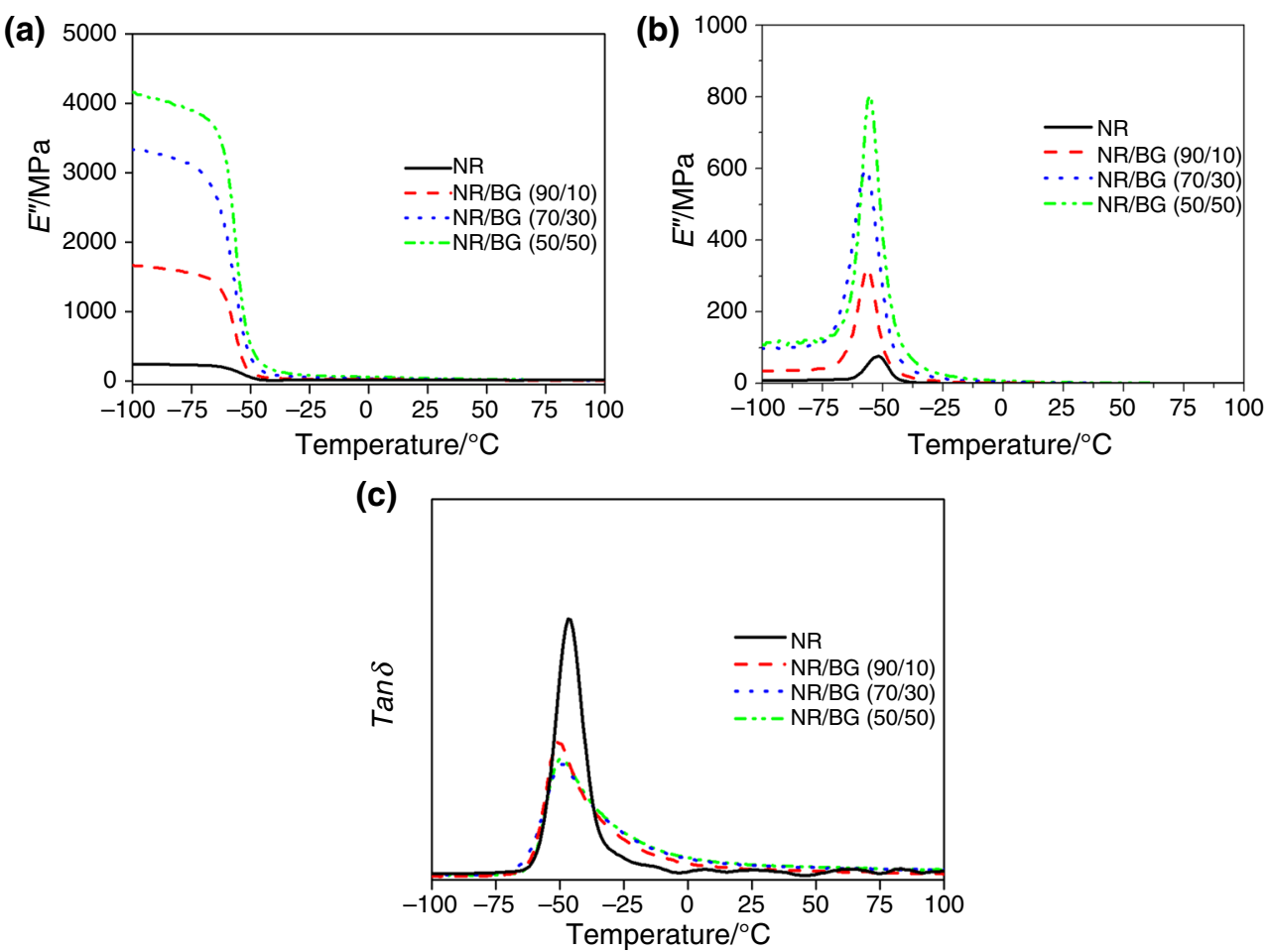

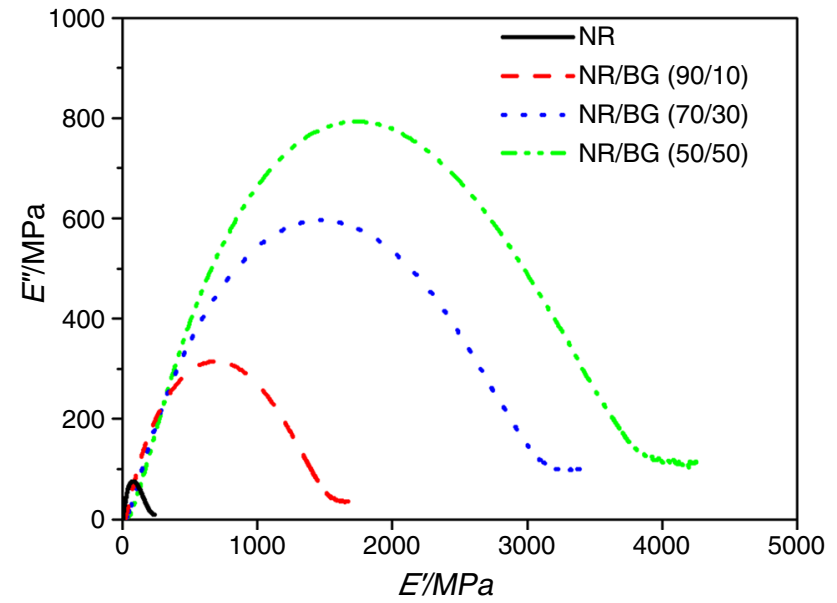

Fig. 5 Cole-Cole diagram of the NR and biocomposite samples

good interaction between the BG particles and the NR matrix. The same behavior occurs with $\sigma_{\text {at break }}$; i.e., it increases with the content of BG particles added to the biocomposites. These improvements in the mechanical properties of the biocomposites can be explained in terms of the mechanical percolation of the BG particles inside the material. When BG particles are dispersed in a polymer matrix, they can form a three-dimensional network of mechanical percolation. This network forms when the fraction of dispersed particles is higher than the percolation

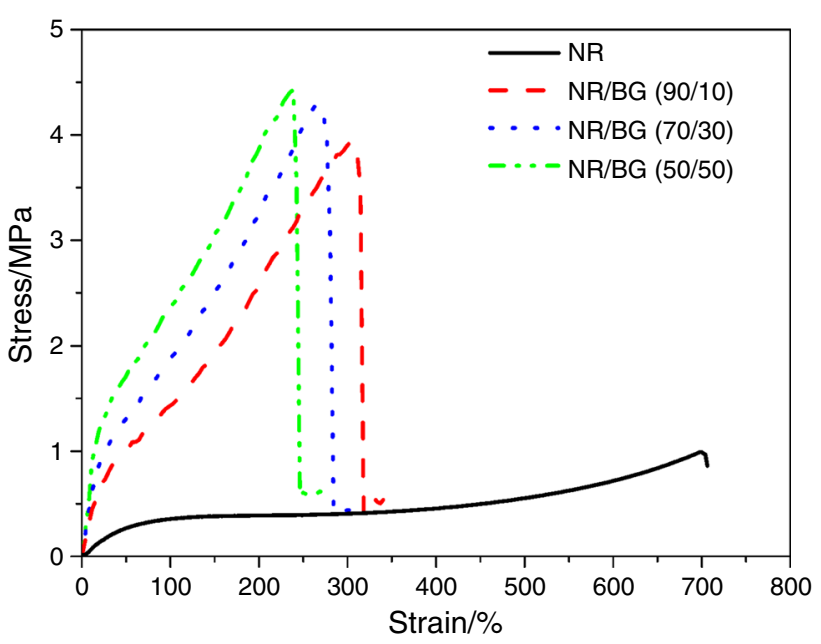

Fig. 6 Stress-strain analyses of the biocomposite samples and NR

Table 2 Mechanical properties of the biocomposites and NR: $Y$ (elastic modulus), $\sigma_{\text {at break }}$ (tensile strength at break), and $\varepsilon_{\text {at break }}$ (elongation at break)

\begin{tabular}{llll}
\hline Samples & Y/Mpa & $\sigma_{\text {at break }} / \mathrm{Mpa}$ & $\varepsilon_{\text {atbreak }} / \%$ \\
\hline NR & $0.41 \pm 0.03$ & $0.98 \pm 0.02$ & $700 \pm 45$ \\
NR/BG (90/10) & $2.23 \pm 0.29$ & $3.98 \pm 0.10$ & $336 \pm 32$ \\
NR/BG (70/30) & $2.87 \pm 0.34$ & $4.30 \pm 0.25$ & $289 \pm 22$ \\
NR/BG (50/50) & $4.61 \pm 0.58$ & $4.42 \pm 0.18$ & $263 \pm 17$ \\
\hline
\end{tabular}


threshold of the system. This mechanical percolation network enables efficiently transferring the applied tension from the polymeric matrix to the BG particles, and as a result, the composite presents mechanical properties superior to those of the matrix [48, 49].

Siqueira et al. [48] studied a composite based on NR reinforced with $\mathrm{CNW}$ and attributed the increase in the mechanical properties to the mechanical percolation phenomenon, where the cellulose nanowhiskers that form a three-dimensional network inside the composite become more efficient at transferring the stress to the reinforcement. Chan et al. [49] also used percolation theory to explain the mechanical behavior of polypropylene biocomposite reinforced with boron nitride and nanohydroxyapatite. According to these authors, the increase in the elastic modulus of the biocomposite with the increase in the particle content in the matrix is related to the mechanical percolation of the particles, which form an interconnected network in the bulk material.

\section{Conclusions}

A very simple synthesis route was employed to obtain natural rubber/Bioglass ${ }^{\circledR} \quad 45 \mathrm{~S} 5$ biocomposites. These materials showed a homogeneous distribution of the BG particles. The thermal analysis showed that the biocomposite samples became more thermally stable than the NR. However, they presented approximately the same thermal profile as that of NR in the TG/DTG curves. Higher storage modulus values were observed for samples with larger amounts of BG, but above the $T_{\mathrm{g}}$, the $E^{\prime}$ value of all the samples tended to zero due to the increased mobility of the polymer chains. The $\tan \delta$ curve yielded $T_{\mathrm{g}}$ values equal to -46 and $-50{ }^{\circ} \mathrm{C}$ for the NR and biocomposite samples, respectively. BG particles improved the mechanical properties of biocomposites compared to those of NR. Stressstrain tests showed that the biocomposite samples had a higher elastic modulus and tensile strength at break $\left(\sigma_{\text {at break }}\right)$ than those of the NR. These results showed that the BG particles improved the thermal and mechanical properties of the NR matrices, making this biocomposite a possible candidate for biomedical applications.

\section{References}

1. Puppi D, Chiellini F, Piras AM, Chiellini E. Polymeric materials for bone and cartilage repair. Prog Polym Sci. 2010;35:403-40.

2. Ige OO, Umoru LE, Aribo S. Natural products: a minefield of biomaterials. ISRN Mater Sci. 2012;2012:1-20.

3. Sykaras N, Iacopino AM, Marker VA, Triplett RG, Woody RD. Implant materials, designs, and surface topographies: their effect on osseointegration. A literature review. Int J Oral Maxillofac Implants. 2000;15:675-90.
4. Boccaccini AR, Gough JE. Tissue engineering using ceramics and polymers. 2nd ed. New York: CRC Press; 2007.

5. Hench LL. The story of Bioglass ${ }^{\circledR}$. J Mater Sci Mater Med. 2006; 17:967-78.

6. Hench LL, Polak JM. Third-generation biomedical materials. Science. 2002;295:1014-7.

7. Reilly GC, Radin S, Chen AT, Ducheyne P. Differential alkaline phosphatase responses of rat and human bone marrow derived mesenchymal stem cells to $45 \mathrm{~S} 5$ bioactive glass. Biomaterials. 2007;28:4091-7.

8. Hench LL, Wilson J. Introduction. In: Hench LL, Wilson J, editors. An introduction to bioceramics. Singapore: World Scientific Publishing Co. Pte. Ltd.; 1993. p. 1-24.

9. Jones JR. Review of bioactive glass: from Hench to hybrids. Acta Biomater. 2013;9:4457-86.

10. Gerhardt LC, Boccaccini AR. Bioactive glass and glass-ceramic scaffolds for bone tissue engineering. Materials. 2010;3:3867-910.

11. Bertolla L, Dlouhý I, Philippart A, Boccaccini AR. Mechanical reinforcement of Bioglass ${ }^{\circledR}$-based scaffolds by novel polyvinylalcohol/microfibrillated cellulose composite coating. Mater Lett. 2014;118:204-7.

12. Eqtesadi S, Motealleh A, Perera FH, Pajares A, Miranda P. Poly(lactic acid) infiltration of 45S5 Bioglass ${ }^{\circledR}$ robocast scaffolds: chemical interaction and its deleterious effect in mechanical enhancement. Mate Lett. 2016;163:196-200.

13. Oliveira AAR, Carvalho SM, Leite MF, Oréfice RL, Pereira MM. Development of biodegradable polyurethane and bioactive glass nanoparticles scaffolds for bone tissue engineering applications. J Biomed Mater Res A. 2012;100:1387-96.

14. Okamoto M, John B. Synthetic biopolymer nanocomposites for tissue engineering scaffolds. Prog Polym Sci. 2013;38:1487-503.

15. Mansur HS, Costa HS. Nanostructured poly(vinyl alcohol)/ bioactive glass and poly(vinyl alcohol)/chitosan/bioactive glass hybrid scaffolds for biomedical applications. Chem Eng J. 2008;137:72-83.

16. Boccaccini AR, Maquet V. Bioresorbable and bioactive polymer/ Bioglass ${ }^{\circledR}$ composites with tailored pore structure for tissue engineering applications. Compos Sci Technol. 2003;63:2417-29.

17. Kim IY, Sugino A, Kikuta K, Ohtsuki C. Bioactive composites consisting of PEEK and calcium silicate powders. J Biomater Appl. 2009;24:105-18.

18. Pon-On W, Charoenphandhu N, Teerapornpuntakit J, Thongbunchoo J, Krishnamra N, Tang I-M. Mechanical properties, biological activity and protein controlled release by poly(vinyl alcohol)-bioglass/chitosan-collagen composite scaffolds: a bone tissue engineering applications. Mater Sci Eng C. 2014;38:63-72.

19. Hild N, Tawakoli PN, Halter JG, Sauer B, Buchalla W, Stark WJ, Mohn D. pH-dependent antibacterial effects on oral microorganisms through pure PLGA implants and composites with nanosized bioactive glass. Acta Biomater. 2013;9:9118-25.

20. Stoppel WL, Ghezzi CE, McNamara SL, Black LD III, Kaplan DL. Clinical applications of naturally derived biopolymer-based scaffolds for regenerative medicine. Ann Biomed Eng. 2014;43:657-80.

21. Gomide VS, Zonari A, Ocarino NM, Goes AM, Serakides R, Pereira MM. In vitro and in vivo osteogenic potential of bioactive glass-PVA hybrid scaffolds colonized by mesenchymal stem cells. Biomed Mater. 2012;7:015004.

22. Eldesoqi K, Henrich D, El-Kady AM, Arbid MS, Abd El-Hady BM, Marzi I, Seebach C. Safety evaluation of a bioglass-polylactic acid composite scaffold seeded with progenitor cells in a rat skull critical-size bone defect. PLoS One. 2014;9:e87642.

23. Dong S, Sun J, Li Y, Li J, Cui W, Li B. Electrospun nanofibrous scaffolds of poly (L-lactic acid)-dicalcium silicate composite via ultrasonic-aging technique for bone regeneration. Mater Sci Eng C. $2014 ; 35: 426-33$. 
24. Rescignano N, Fortunati E, Montesano S, Emiliani C, Kennya JM, Martino S, Armentano I. PVA bio-nanocomposites: a new take-off using cellulose nanocrystals and PLGA nanoparticles. Carbohyd Polym. 2014;99:47-58.

25. Marelli B, Ghezzi CE, Barralet JE, Boccaccini AR, Nazhat SN. Three-dimensional mineralization of dense nanofibrillar collagen-bioglass hybrid scaffolds. Biomacromolecules. 2010;11: 1470-9.

26. Liang SL, Cook WD, Thouas GA, Chen QZ. The mechanical characteristics and in vitro biocompatibility of poly(glycerol sebacate)-Bioglass ${ }^{\circledR}$ elastomeric composites. Biomaterials. 2010;31:8516-29.

27. Hajiali H, Hosseinalipour M, Karbasi S, Shokrgozar MA. The influence of bioglass ${ }^{\circledR}$ nanoparticles on the biodegradation and biocompatibility of poly(3-hydroxybutyrate) scaffolds. Int J Artif Organs. 2012;35:1015-24.

28. Chen Q, Garcia RP, Munoz J, Larraya UP, Garmendia N, Yao Q, Boccaccini AL. Cellulose nanocrystals-bioactive glass hybrid coating as bone substitutes by electrophoretic co-deposition; in situ control of mineralization of bioactive glass and enhancement of osteoblastic performance. ACS Appl Mater Interfaces. 2015;7:24715-25.

29. Li L, Zuo Y, Zou Q, Yang B, Lin L, Li J, Li Y. Hierarchical structure and mechanical improvement of an n-HA/GCO-PU composite scaffold for regeneration. ACS Appl Mater Interface. 2015;7:22618-29.

30. Cornish K. Similarities and differences in rubber biochemistry among plant species. Phytochemistry. 2001;57:1123-34.

31. Mark HF, Bikales NM, Oberberger CG, Menges G. Encyclopedia of polymer science and technology. 3rd ed. New York: Wiley; 2003.

32. Frade AA, Valverde RV, Assis RV, Coutinho-Netto J, Foss NT. Chronic phlebopathic cutaneous ulcer: a therapeutic proposal. Int J Dermatol. 2001;40:238-40.

33. Steinbüchel A. Production of rubber-like polymers by microorganisms. Curr Opin Microbiol. 2003;60:261-70.

34. Araujo MM, Massuda ET, Hyppolito MA. Anatomical and functional evaluation of tympanoplasty using a transitory natural latex biomembrane implant from the rubber tree Hevea brasiliensis. Acta Cirúrgica Brasileira. 2012;27:566-71.

35. Silva GA, Coutinho OP, Ducheyne P, Reis RL. Materials in particulate form for tissue engineering applications in bone. J Tissue Eng Regen Med. 2007;1:97-109.

36. Nascimento RM, Faita FL, Agostini DLS, Job AE, Guimarães FEG, Bechtold IH. Production and characterization of natural rubber- $\mathrm{Ca} / \mathrm{P}$ blends for biomedical purposes. Mater Sci Eng C. 2014;39:29-34.
37. Borges FA, Bolognesi LFC, Trecco A, Drago BC, Arruda LB, Filho PNL, Pierri EG, Graeff CFO, Santos AG, Miranda MCR, Herculano RD. Natural rubber latex: study of a novel carrier for Casearia sylvestris Swartz delivery. ISRN Polym Sci. 2014;2014:1-5.

38. Bolognesi LFC, Borges LA, Cinman JLF, Silva RG, Santos AG, Herculano RD. Natural latex films as carrier for casearia sylvestris swartz extract associated with ciprofloxacin. Am Chem Sci J. 2015;5:17-25.

39. Barboza-Filho CG, Cabrera FC, Dos Santos RJ, De Saja Saez JA, Job AE. The influence of natural rubber/Au nanoparticle membranes on the physiology of Leishmania brasiliensis. Exp Parasitol. 2012;130:152-8.

40. Oliveira LCS, Arruda EJ, Costa RB, Gonçalves PS, Delben A. Evaluation of latex from five Hevea clones grown in São Paulo State, Brazil. Thermochim Acta. 2003;398:259-63.

41. Silva MJ, Sanches AO, Medeiros ES, Mattoso LHC, McMahan CM, Malmonge JA. Nanocomposites of natural rubber and polyaniline-modified cellulose nanofibrils. J Therm Anal Calorim. 2014;117:387-92.

42. Jawaid M, Abdul Khalil HPS, Alattas OS. Woven hybrid biocomposites: dynamic mechanical and thermal properties. Compos A. 2012;43:288-93.

43. Ornaghi HL, Bolner AS, Fiorio R, Zattera AJ, Amico SC. Mechanical and dynamic mechanical analysis of hybrid composites molded by resin transfer molding. J Appl Polym Sci. 2010;118:887-96.

44. Sanches AO, Ricco LHS, Malmonge LF, Silva MJ, Sakamoto WK, Malmonge JA. Influence of cellulose nanofibrils on soft and hard segments of polyurethane/cellulose nanocomposites and effect of humidity on their mechanical properties. Polym Test. 2014;40:99-105.

45. Manoharan S, Suresha B, Ramadoss G, Bharath B. Effect of short fiber reinforcement on mechanical properties of hybrid phenolic composites. J Mater. 2014; . doi:10.1155/2014/478549.

46. Jawaid M, Abdul Khalil HPS, Hassan A, Dungani R, Hadiyane A. Effect of jute fiber loading on tensile and dynamic mechanical properties of oil palm epoxy composites. Compos B. 2013;45:619-24.

47. Uma Devi L, Bhagawan SS, Thomas S. Dynamic mechanical analysis of pineapple leaf/glass hybrid fiber reinforced polyester composites. Polym Compos. 2010;31(6):956-65.

48. Siqueira G, Abdillahi H, Bras J, Dufresne A. High reinforcing capability cellulose nanocrystals extracted from Syngonanthus nitens (Capim Dourado). Cellulose. 2010;17:289-98.

49. Chan KW, Wong HM, Yeung KWK, Tjong SC. Polypropylene biocomposites with boron nitride and nanohydroxyapatite reinforcements. Materials. 2015;8:992-1008. 